\title{
HOTS in teacher classroom interaction: A case study
}

\author{
1Yuyun Yulia* \\ 1Fenita Rizki Budiharti \\ ${ }^{1}$ English Education Program, Universitas Sarjanawiyata Tamansiswa, \\ Yogyakarta, Indonesia
}

*Corresponding Author

Email: yuyun.yulia@ustjogja.ac.id

\begin{abstract}
As Goronga (2013) notes that classroom interaction encourages students to actively participate in teaching learning process. Teacher question plays an important role to trigger students' critical thinking or Higher Order Thinking Skills (HOTS). This paper highlights questions revealed in teaching learning process that triggering students' critical thinking. Class observation and interview is conducted and then analyzed based on Bloom's taxonomy. Data eventually show that remembering is mostly uttered to stimulate the students to state what they know about the topic and recall particular information. This means teachers find difficulties to practice questions with HOTS aspects. Teachers need to have more practice on how to encourage students to have critical thinking as one of skills in this disruptive era.
\end{abstract}

Keywords : HOTS; classroom interaction; teacher question; critical thinking

Received:

28 July 2019
Revised:

28 August 2019
Accepted:

28 August 2019
Published:

31 August 2019

\section{INTRODUCTION}

In this industrial revolution 4.0, characters, in particular, creativity, collaboration, critical thinking and communication are badly needed for both teachers and students to actively participate in the process of teaching and learning. In communication, for example, Yulia (2014) finds out that teachers find difficulties to motivate students to learn English, in particular, to improve students' speaking competence. Nations (2003) contends that learning English both in foreign and second language contexts needs four strands, that is meaning focused input (listening and reading), meaning focused output (speaking and writing), language focused learning (attention to language features) and fluency development (working with known material).

The aim of teaching English in schools based on the Decree of the Minister of Education and Culture No. 060/U/1993 dated 25 February 1993 and the 1989 Constitution on the System of National Education is to enable students to be proficient in English in the globalization era Rachmajanti (2008). Meanwhile, Nurkamto (2003) asserts that "the aim of the teaching of English in the schools has been to develop the students' communicative 
Yulia, Budiharti, EduLite: Journal of English Education, Literature, and Culture Vol.4, No.2, August 2019, 132-141 DOI: http://dx.doi.org/10.30659/e.4.2.132-141

competence. It can be said that students are expected to be proficient in English for their future to face the globalization era.

To enable the students to be proficient in English, teachers have an important role for the students in teaching and learning process. Teachers need to encourage students to be actively engaged to create conducive and communicative teaching and learning process. It is important to build good interaction between teachers and students. In order to help students to participate actively, teachers need to stimulate student critical thinking by asking questions revealing Higher Order Thinking Skills (HOTS).

Classroom interaction is expected to occur in the EFL classroom. A good classroom interaction depends on how teachers give a chance to students to talk each other, ask or share the information they get during the lesson. Khan cited in Putri (2014) claims that classroom interaction contributes to the students being active in the learning process.

To stimulate students to speak actively, questions are needed in the teaching and learning process. Elder (2003) concluded that question define tasks and express problem and issues.

One of the best-known classifications of question is based on Bloom's taxonomy. In 2001, Anderson et al. revised Bloom's taxonomy that provides six major categories in the cognitive domain; the categories are knowledge, comprehension, application, analysis, synthesis and evaluation. In revised Bloom's taxonomy, it provides a framework for teachers to design questions and task to get range of thinking skill. The followings are students six levels of criteria of thinking process to develop questions including:

1. Remembering It is to test students' ability to recognize or recall knowledge from memory.

2. Understanding

It tests students' ability to construct meaning from different types of functions be they written or graphic messages or activities like interpreting, exemplifying, classifying, and so on.

3. Applying

It is to carry out or use a procedure through executing or implementing.

4. Analyzing

It is to break materials or concepts into parts, determine how the parts relate to one another or how they interrelate, or how the parts relate to an overall structure or purpose.

5. Evaluating

In evaluating level, students are able to make judgments based on criteria and standards through checking and critiquing.

6. Creating

These questions encourage students to put elements together to form a coherent or functional whole; reorganize elements into a new pattern or structure through generating, planning, or producing.

In the teaching and learning process, it is common to find situations in which students cannot answer the teacher's questions. This is happening because the students are reluctant to answer or they really do not know the 
answer (Tan, 2007). In English classroom, it is frequently found that the students cannot answer the questions not because of reluctance of the knowledge; rather they get difficulties to express their answer in English. It means that students have insufficient proficiency ability to answer the questions is commonly happened in classroom interaction.

Questioning is one of the functional features of the teacher's talk. The importance of question has been discussed a lot by scholars. In the field of second language acquisition, scholar defined questions from a different perspective. Cotton (2001) claims that question is any sentence that has an interrogative form or function. Elder and Paul (2003: 3), for instance, indicate that question define tasks and express problem and issues. The answer, on the other hand, is often a full stop in thought. Elder and Paul (2003) assert that effective questioning leads to the transformation of the students' thoughts and ideas.

In teaching and learning context, questions refer to some ideas that need response from the hearer; in this context, it is common to have teachers question and students answer. It is used for asking or requesting for information. Moreover, the request is made by some expressions and the information is provided with the answer. To invite classroom participation, teachers ask and students give responses by answering teachers' questions. Phuong and Vo (2019) noted that student involvement is considered to be one of factors influencing student English proficiency. Student classroom involvement impacts upon student achievement; in other words, the more students engage in teaching learning process, the better achievement of their English language proficiency will be (Hamzah, Hilmi and Thivya, 2016)

Modified and effectively rephrased question can avoid ambiguity. It can encourage students to participate actively in the discussion. Moreover, it can help students in improving their productive skills. Chaudron (1988) proposes techniques of modifying questions, they are: repetition, narrowing by means of clues, rephrasing with alternative or "or choice" questions and wait-time.

\section{DISCUSSION}

The purpose of the research was to describe teacher question in the EFL classroom and to identify the most dominant of questions types. The data were collected through interview and class observation of ten graders of SMA N 2 Banguntapan. In analyzing the data, the researchers employed Cresswell (2014) procedures, that is, organizing and preparing the data, reading through all the data, coding all the data and classified utterances using Bloom Taxonomy, making interpretation and finally conclusion is drawn.

Based on data of direct observation, the researchers found out various question types. As Bloom classification, the questions are remembering, understanding, applying, analyzing, evaluating and creating. Below is the table of frequency and percentage of questions posed by teacher during the teaching and learning process. 
Yulia, Budiharti, EduLite: Journal of English Education, Literature, and Culture Vol.4, No.2, August 2019, 132-141 DOI: http://dx.doi.org/10.30659/e.4.2.132-141

Table 1 : The Occurrence of Teacher Question

\begin{tabular}{|c|c|c|c|c|}
\hline \multirow[t]{2}{*}{ Types of Question } & \multicolumn{4}{|c|}{$\begin{array}{l}\text { Frequency and percentage of occurrence of } \\
\text { questions }\end{array}$} \\
\hline & $\begin{array}{l}\text { First } \\
\text { meeting }\end{array}$ & $\%$ & $\begin{array}{l}\text { Second } \\
\text { meeting }\end{array}$ & $\%$ \\
\hline Remembering & 27 & $71.1 \%$ & 12 & $52.2 \%$ \\
\hline Understanding & 9 & $23.7 \%$ & 7 & $30.4 \%$ \\
\hline Applying & - & - & - & - \\
\hline Analyzing & 1 & $2.6 \%$ & 3 & $13 \%$ \\
\hline Evaluating & - & - & - & - \\
\hline Creating & 1 & $2.6 \%$ & 1 & $4.3 \%$ \\
\hline Total & 38 & $100 \%$ & 23 & $100 \%$ \\
\hline
\end{tabular}

Among questions types, remembering level was found to be the most frequently used in classroom interaction by frequency of 27 questions and total percentage of $71.1 \%$. Understanding level is ranked second by occurrence in total nine questions and total percentage of $23.7 \%$ analyzing and creating level is one question and total percentage of $2.6 \%$. In second meeting, the teacher posed 23 questions that were categorized based on Bloom taxonomy. In the first rank, remembering level is dominantly used with a total number of 12 questions or $52.3 \&$ the second rank was understanding level by frequency of seven or a total research of $30.4 \%$. Then, the third rank was analyzing level by frequency of two questions or a total research of $13 \%$ and the last question in level is creating level. It was found one question with total percentage of $4.3 \%$. In the research findings, the other types of questions such as applying and evaluating were not found in this research.

The findings showed that the teacher posed a lot of questions in remembering level. Students, in this case, are stimulated to recall or remember the information given by the teacher. The activities included: mention the definition, imitate the pronunciation, state the structure, pronounce, repeat, state. The majority of the utterances belong to recall the students' knowledge.

\begin{tabular}{|ll|}
\hline $\mathrm{T}$ & $\begin{array}{l}\text { : In our previous meeting, kita lanjutkan yang kemarin. What we } \\
\text { have talked about? Yang kita bahas minggu lalu apa? }\end{array}$ \\
$\mathrm{LL}$ & $:$ Narrative \\
$\mathrm{T}$ & $\begin{array}{l}\text { : Narrative? Iya. In narrative what kind of tenses that we learn? } \\
\text { Tenses yang kita pelajari dinarrative itu apa? Verb nya bentuk } \\
\text { keberapa kemarin? }\end{array}$ \\
$\mathrm{LL}$ & $:$ kedua \\
$\mathrm{T}$ & : Ok, that's right, bentuk yang kedua. \\
\hline
\end{tabular}

The teacher said, "yang kita bahas minggu lalu apa?" to recall students' memory of previous material. This question is classified into knowledge level. In the next question "In narrative what kind of tenses that we learn? Tenses yang kita pelajari dinarrative itu apa? Verb nya bentuk keberapa kemarin?", the teacher elaborated the question to reconfirm the previous question. 


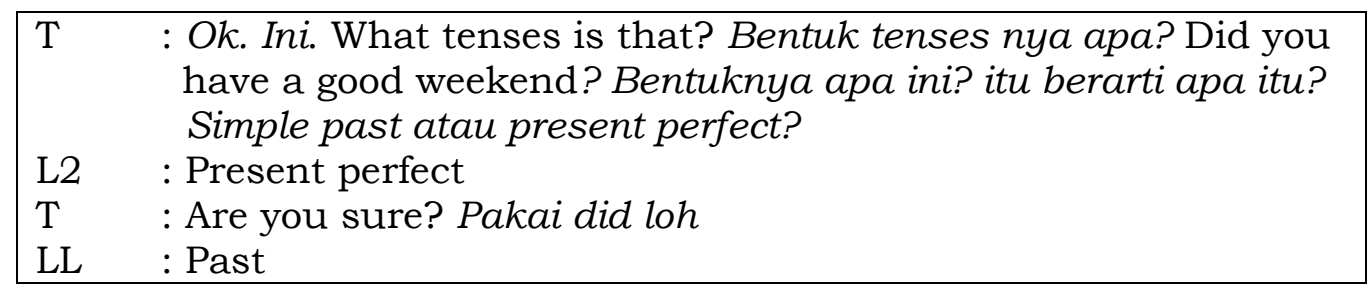

The teacher asked a question to the students "Bentuk tenses nya apa? Did you have a good weekend?" to encourage students to identify what tenses used in the sentence. The next question "Are you sure? Pakai did loh" to ask students to recall their knowledge of simple past tense and present perfect tense. This question is categorized onto remembering level.

In the next observation, it was found that teacher also posed a lot of questions which were at remembering level.

$$
\begin{array}{ll}
\mathrm{T} & \text { : Did you still remember? Kita minggu lalu bahas apa? } \\
\mathrm{L} 1 & \text { : Nganu bu, past tense sama apa itu satunya } \\
\mathrm{T} & : \text { Apa hayo? } \\
\mathrm{L} 1 & \text { : Oh, present perfect bu } \\
\mathrm{T} & \text { : Yaa.. Nah, kemarin itu kalo past tense cirinya apa? } \\
\mathrm{LL} & \text { : Pake verb } 2 \mathrm{bu}
\end{array}
$$

The teacher posed a question "Did you still remember? Kita minggu lalu bahas apa?" to guide student to recall or remember what they learnt last week. Then, she continued to ask a question "Yaa.. Nah, kemarin itu kalo past tense cirinya apa?" was a question to ask students to mention the characteristics of simple past tense. These questions were categorized into remembering level because the question focused on recalling students' knowledge of the detail related to the topic discussed, in this case, knowledge about the language.

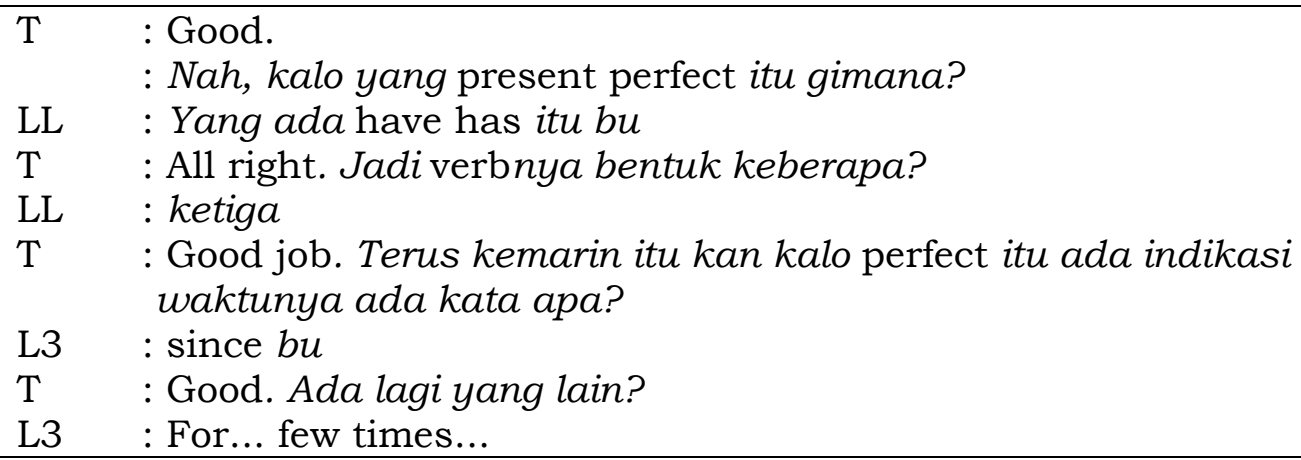

The teacher asked the students, "Nah, kalo yang present perfect itu gimana?". It is to stimulate students to recall student knowledge of present perfect. Then, she continued to ask "All right. Jadi verbnya bentuk keberapa?" to encourage students to mention the detail of present perfect tense. 
Yulia, Budiharti, EduLite: Journal of English Education, Literature, and Culture Vol.4, No.2, August 2019, 132-141 DOI: http://dx.doi.org/10.30659/e.4.2.132-141

Besides remembering, the teacher posed several questions which belong to understanding level. The following extract shows understanding level of question,

\begin{tabular}{|ll|}
\hline $\mathrm{L}$ & : Did you leave him? \\
$\mathrm{T}$ & : Ok, Ndoko bertanya pada salah satu temen ceweknya dikelas \\
& ya. Did you leave him? Nah, what does it mean, Dinar? Artinya \\
& apa le? \\
$\mathrm{L}$ & $:$ Apakah kamu meninggalkan dia?
\end{tabular}

The teacher asked one of the students, "Did you leave him? Nah, what does it mean, Dinar? Artinya apa le?". The teacher asked about the meaning of the sentences they were discussing. The question is categorized into understanding level because it involves translating activity.

\begin{tabular}{|ll|}
\hline $\mathrm{T}$ & $:$ Ok, what are the differences between these sentences below? \\
& Apa artinya? \\
$\mathrm{L}$ & $:$ Apa perbedaan diantara kalimat dibawah ini \\
$\mathrm{T}$ & $:$ Very good, check it out.
\end{tabular}

The question, "Apa artinya?" is categorized into understanding level. Teacher posed this question to ask the students to translate the sentence into the students' first language.

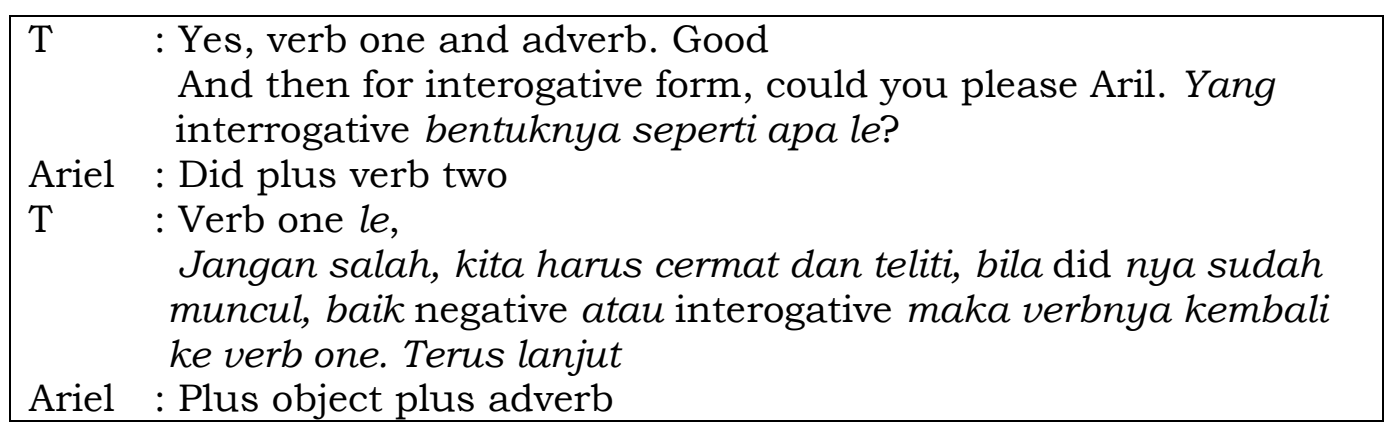

In datum, "And then for interrogative form, could you please Aril. Yang interrogative bentuknya seperti apa le?" is to ask students to identify the sentence and mention the formula. The question is categorized into understanding level.

\begin{tabular}{|ll|}
\hline $\mathrm{T}$ & $\begin{array}{l}\text { : All right. Jadi bedanya dua kalimat itu apa? Ada yang bisa } \\
\text { menjelaskan? }\end{array}$ \\
$\mathrm{L6}$ & : Yang satu pake verb 2 bu, yang satu pakai verb 3 \\
\hline
\end{tabular}

Teacher asked "Jadi bedanya dua kalimat itu apa? Ada yang bisa menjelaskan?". The question is to stimulate students to identify two sentences and explain the differences between them; so, it is categorized as analyzing level question. 


\begin{tabular}{|l}
\hline T : And could you please create ten sentences. Five for simple past \\
tense and five for present perfect tense. Do it at home ya. \\
LL $\quad:$ Iya bu.
\end{tabular}

The teacher posed a question "And could you please create ten sentences. Five for simple past tense and five for present perfect tense. Do it at home $y a$ ". The teacher asked them to create sentence though it is done at home. This seems to question revealing higher order thinking skills (HOTS).

Table 2: The Occurrence of Teacher Question

\begin{tabular}{lcccc}
\hline \multirow{2}{*}{ Thinking skill } & \multicolumn{4}{c}{ Frequency and percentage of occurrence of question } \\
\cline { 2 - 5 } & First meeting & $\%$ & Second meeting & $\%$ \\
\hline HOTS & 2 & $5.3 \%$ & 4 & $17.4 \%$ \\
\hline LOTS & 36 & $94.7 \%$ & 19 & $82.6 \%$ \\
\hline
\end{tabular}

Table 2 shows that mostly teacher posed LOTS level questions in the first meeting and second meeting. The teacher posed 27 questions in remembering level and 9 questions in understanding level which belongs to LOTS questions. Teachers posed HOTS questions which consist of one analyzing level question and one creating level questions. In the second meeting teacher posed in total 19 questions which also belong to LOTS question which consist of 12 questions in remembering level questions and seven questions in understanding level questions. HOTS questions in total four questions consist of three questions in analyzing level questions and one creating level questions. The most dominant of teacher question that posed by the teachers was remembering level questions. In other words, the most dominant questions types posed during the lesson were LOTS questions.

It can be concluded that the teacher in both meetings posed a lot of questions which were in remembering level. According to Brown (2007) recall questions are the most common type of questions asked by teachers because the information has to be known before they can be applied and curricular objectives and examinations often stress factual content.

In teaching and learning process, the teachers mostly used L1 to interact with the students. They noted that Bahasa Indonesia was used during the lesson to save time, avoid lengthy explanations in the target language and help students to comprehend the question easier. This is in line with Yulia's finding (2014) that teachers tend to speak in Bahasa Indonesia to ease student to understand.

In brief, teachers posed a lot of at remembering level. In order words, they pose more low order thinking skills (LOTS) that might be impacted upon low exposure on student creativity as well as critical thinking. it is in line with Gall (1970) concluding that about 60 researches of teacher question require students to recall facts; about 20 researches require students to think; and the remaining 20 research are procedural. There are some reasons why the questions of remembering level dominated in this research, they are as follows:

1. Teacher competence in teaching English in particular speaking competence need to be revealed in class. Based on the observations, the teacher asked a 
Yulia, Budiharti, EduLite: Journal of English Education, Literature, and Culture Vol.4, No.2, August 2019, 132-141 DOI: http://dx.doi.org/10.30659/e.4.2.132-141

lot of questions in remembering level questions. This means that the teachers focused merely on recognizing and recalling students' knowledge. Question in the level of HOTS is limited. Alkhaleefah (1996), said that classroom questions were considered as an important skill in teaching because they reflect teachers' capability and competence in formulating and directing questions to students at a level that evokes their interest, and dealing with their reactions, since teachers develop their positive from anxiety and fear. As well, Walsh (2011) argued that the need of language teaching professional to ask appropriate questions and emphasize the complexity attached to good questions.

2. It was found that students were not too interested in learning English, and they have low motivation in learning English. It can be seen from how they respond to teacher question and motivation to learn English. William and Burden (1997) point out that learning was possible to occur when people want to do it.

3. The situation of teaching and learning English also influenced by the teachers in asking questions in teaching and learning process. Based on the interview, the teacher found difficulties to use why question to the students.

4. The material of lesson. In this research, the material of lesson was about simple past tense and present perfect tense. The teachers focused on recalling students' knowledge about simple past tense and present perfect tense. In teaching and learning process teacher dominantly ask students to state what tenses used in the sentence. Zaennudin (2016) pinpoints that the use of authentic material and classroom discussion technique facilitates the teacher to use types of questions.

The teachers focused on recalling students' memory about the topic given. The questions that stimulated students to think higher was limited. In addition, the students competence also gave impact to the teacher posed the question's types. During the teaching and learning process the students were not interested in learning English.

The teachers said that she wanted to ask questions that encourage students to think higher. However, the students avoided to answer questions. In this research, the material of the lesson was simple past tense and present perfect tense. The teacher focused on recalling students' knowledge about the structure and detail of each tenses.

Among questions types, remembering level were found to be most frequently occurring question types in teaching and learning process. There are some reasons why the questions in remembering level dominated in this research, they are: (1) teacher's competence in teaching English, (2) students' competence in learning English, (3) the situation during the teaching and learning process, (4) the material given by the teacher in teaching and learning process.

Overall, it can be concluded that teacher question is influenced by teacher competence, students' competence, situation of teaching and learning process, and the material of the lesson. It is in line with the result of research 
by Swift (2004) who reported that the presence of significant positive relation between teacher effectiveness in lesson explanation, method in asking questions, and their competence in teaching.

\section{CONCLUSION}

As Chaudron (1988) concluded that $20 \%-40 \%$ of class talks are questions, classroom English exposure need to be revealed in the process of teaching and learning. To engage student critical thinking, teachers need to have sufficient language exposure triggering student higher order thinking skills. In fact, this research revealed remembering questions seem to be frequently used by teachers in classroom interaction. Remembering level questions stimulate students to recall and state the information they got. Teachers need to note that they are language model in class, thus, their classroom language should be good and proficient as well as they should be able to create questions that provide critical thinking of students.

\section{REFERENCES}

Anderson, L., Krathwohl, m. R., Airasian, P. W., Cruikshank, K. A., Mayer, R. E., Pintrich, P. R. (2001). A Taxonomy for Learning, Teaching, and Assessing: A Revision of Bloom's Taxonomy of Educational Objectives (Complete edition). New York: Longman.

Brown, H. D. (2007). Teaching by Principles An Interactive Approach to Language Pedagogy. San Fransisco, California: Longman.

Chaudron, C. (1988). Second Language Classrooms : Research on Teaching and Learning. Cambridge: Cambridge University Press.

Cotton, K. (2001). Classroom Questioning. North West Regional Educational Laboratory.

Creswell, J. W. (2014). Research Design: Qualitative, Quantitative and Mixed Methods Approaches. Fourth Edition. Sage Publications, Inc.

Elder, L. and Paul, R. (2003). Critical Thinking: Teaching Students How to Study and Learn. Journal of Developmental Education, 27 (2), 36-38.

Gall, M. D., (1970). "The Use of Questions in Teaching". American Educational Research Association. Vol. 40, No. 5, pp. 707-721. DOI: $10.2307 / 1169463$

Goronga, P. (2013). The nature and quality of classroom verbal interaction: Implications for primary school teachers in Zimbabwe. 431-444.

Hamzah, Mohd Hilmi \& Asokan, Thivya. (2016). The Effect of Participation Instruction on ESL Students' Speaking Skills and Language Anxiety. International Conference of Higher Order Thinking Skills 2016 in Conjunction with 2 nd International Seminar on Science and Mathematics Education 2016. 
Yulia, Budiharti, EduLite: Journal of English Education, Literature, and Culture

Available at

https://www.researchgate.net/publication/303334588_The_Effect_of_Pa rticipation_Instruction_on_ESL_Students'_Speaking_Skills_and_Languag e_Anxiety

Khan, R. N. (2009). Classroom Interaction in ESL Classrooms : A Comparative Study between Group Work and Individual Work. Unpublished Degree's dissertation, Brac University.

Nation, P. (2003). The Role of the First Language. Asian EFL Journal, 5(2) pp. 1-8, retrieved June 17, 2013.

Nurkamto, J. (2003). Problem Pengajaran Bahasa Inggris di Indonesia. Jurnal Ilmiah Masyarakat Linguistik Indonesia, 288-307.

Phuong, H. Y. \& Vo, P. Q. (2019). Students' Learning Autonomy, Involvement and Motivation Towards Their English Proficiency. Edulite: Journal of English Education, Literature and Culture, Vol. 4, No. 1, February 2019, pp. 1-12.

Putri, F. G. (2014). An Analysis of Classroom Interaction by Using Flander Interaction Analysis Categories System (FIACS) Technique at SMPN 13 Kota Bengkulu in 2013/2014 Academic Year.

Rachmajanti, S. (2008). Impact of English Instruction at the Elementary Schools on the Students' Achievement of English at the Lower Secondary School. TEFLIN Journal, 161.

Swift, J. (2004). Wait Time and Questioning Skills of Middle School ScienceTeachers. Roeper Review, 64-66.

Tan, Z. (2007). Questioning in Chinese University EL Classroom. Regional Language Centre (RELC) Journal, 87-102.

Walsh, S. (2011). Exploring Classroom Discourse: Language in Action. London: Routledge.

Williams, M., \& Burden, L. R., (1997). Psychology for Language Teachers: A Social Constructivist Approach. Cambridge University Press.

Yulia, Y. (2014). Teaching Challenges in Indonesia: Motivating Students and Teachers' Classroom Language, Indonesian Journal of Applied Linguistics, Vol. 3, No. 1, July 2013, pp 1-16.

Zaennudin. (2016). Types of Teacher's Questions and Students Responses in Developing Communicative Classroom Interaction: A Case Study of Questioning in SMKN 1 Lembar. IJLOT, 111-123. 